\title{
Epidemiological Study of Glucose-6-phosphate Dehydrogenase Deficiency in Scheduled Caste Population of India
}

\author{
Vandana Rai and Pradeep Kumar \\ Human Molecular Genetics Laboratory, Department of Biotechnology, VBS Purvanchal University, \\ Jaunpur 22001, India \\ Correspondence should be addressed to Vandana Rai, raivandana@rediffmail.com
}

Received 26 November 2011; Revised 23 February 2012; Accepted 29 February 2012

Academic Editor: Santos Alonso

Copyright ( 92012 V. Rai and P. Kumar. This is an open access article distributed under the Creative Commons Attribution License, which permits unrestricted use, distribution, and reproduction in any medium, provided the original work is properly cited.

The aim of the present study was to determine the glucose-6-phostphate dehydrogenase (G6PD) deficiency in scheduled caste (SC) population of eastern Uttar Pradesh, India. After taking clearance certificate from the Institutional Ethics Committee, blood samples were collected from total 200 healthy individuals belonging to scheduled caste. G6PD deficiency analysis was done by methemoglobin test according to the method of Brewer et al. (1962). Out of 200 samples, 20 individuals were glucose-6-phosphate dehydrogenase deficient and 22 samples were heterozygous that is, carriers. The percentage of G6PD deficient (Gd+/+) and G6PD carrier $(\mathrm{Gd}+/ \mathrm{Gd}-)$ phenotypes were $10 \%$ and $11 \%$, respectively. The frequency of mutant allele (Gd-) was observed 0.172 . Early detection and prevention is the key strategy for successful management and control of this genetic disease.

\section{Introduction}

Glucose-6-phosphate dehydrogenase (G6PD) is a highly conserved housekeeping enzyme and rate-limiting enzyme of the pentose phosphate pathway in all cells [1]. The pentose phosphate pathway (PPP) converts glucose to ribose-5-phosphate, a precursor to RNA, DNA, ATP, CoA, NAD, and FAD. In addition, in mammalian cells G6PD provides reductive potential in the form of NADPH [2]. G6PD is a ubiquitous enzyme that must be quite ancient in evolution because it has been found in all organisms, from prokaryotes to yeasts, to protozoa, to plants, and animals $[3,4]$. G6PD deficiency results from mutations in the G6PD gene and is well-known common cause of hemolytic anemia in human [5]. Most cells have a back-up system of other metabolic pathways that can generate the intracellular NADPH necessary, but red blood cells do not have the other NADPH producers. Therefore, G6PD deficiency becomes especially lethal in red blood cells, where any oxidative stress will result in hemolytic anemia. G6PD deficiency was first identified in American blacks in the course of studies of sensitivity to the hemolytic effect of primaquine [6]. Clinically, this deficiency affects as many as 400 million individuals worldwide [3] and predisposes affected individuals to neonatal jaundice, drug- or infectionmediated hemolytic crisis, favism, and, less commonly, to chronic nonspherocytic hemolytic anemia [7].

The G6PD gene is present on the long arm of the $\mathrm{X}$ chromosome (Xq28) and consists of 13 exons with a length of $18 \mathrm{~kb}$ [8]. The active form of G6PD enzyme is either a dimer or a tetramer of a single polypeptide subunit of about $59 \mathrm{kD}$ [9]. G6PD deficiency is mainly found in populations originating from tropical and subtropical areas of the world and geographic distribution is similar to that of falciparum malaria. This deficiency is beneficial as it is known that red cells that are deficient in G6PD are resistant to Plasmodium falciparum invasion since the parasite require the enzyme for its normal survival in the host cell [10]. This deficiency offers a selective protection against $P$. falciparum malaria [11]. It has, however, been reported that some $P$. falciparum parasite strains have been able to synthesize their own G6PD enzyme thereby evading the immunity offered by G6PD deficiency in such individuals [12].

In India, G6PD deficiency was first reported in 1963 by Baxi et al. [13], and the prevalence rate varied from 0 to $27 \%$ in different caste, ethnic, and linguistic groups [14]. The frequency is higher among the tribals than the caste 
TABLE 1: Distribution of the glucose-6-phosphate dehydrogenase enzyme phenotypes and their allele frequencies among SC samples.

\begin{tabular}{lcccc}
\hline & Normal $(\mathrm{Gd}+/ \mathrm{Gd}+)$ & Heterozygous $(\mathrm{Gd}+/ \mathrm{Gd}-)$ & Deficient $(\mathrm{Gd}-/ \mathrm{Gd}-)$ & Allele frequencies \\
\hline Total samples & 158 & 22 & 20 & $\mathrm{Gd}+=0.828$ \\
Males & 92 & 00 & 11 & $\mathrm{Gd}-=0.172$ \\
Females & 66 & 22 & 09 & \\
\hline
\end{tabular}

populations [15]. Studies in the last few years also support the trend. Warli and Dhodia, tribal populations in Dadra and Nagar, Haveli have a frequency of $10.1 \%$ [16] and $13.5 \%$ [17], respectively, while Rajput, caste group from the same geographical region, has low frequency of $2.1 \%$ [18]. The prevalence of G6PD deficiency has been extensively studied in several population groups; however, there is no information about G6PD deficiency from different caste groups of Uttar Pradesh. Hence, the aim of the present study was to determine the frequency of glucose-6-phosphate deficiency among the scheduled caste population of Uttar Pradesh, India.

\section{Materials and Method}

Ethical clearance certificate was taken for the present study from the VBS Purvanchal University Ethics Committee, and the study conducted from October 2009 to April 2010. Blood samples were collected from the young healthy adults of scheduled caste population belonging to both sexes. After an informed consent, a brief clinical record including age, ethnic group, place of residence, and history of past illnesses including fever and episodes of recurrent jaundice was recorded. Four-milliliters cubed blood was collected from each subject in acid citrate dextrose (ACD) coated vials. Glucose-6-phosphate dehydrogenase deficiency analysis was done by methemoglobin test according to the method of Brewer et al. [19]. The test is based on methemoglobin production by addition of nitrites in test blood, and then process of methemoglobin reduction to oxyhemoglobin is triggered by methylene blue. Positive controls and negative controls were employed in each batch. Gene frequency was calculated by simple gene count method.

\section{Result and Discussion}

Total 200 scheduled caste samples were collected and analyzed for G6PD deficiency. In 200 SC samples, 103 samples are of males and 97 are of females. Out of 200 samples, 20 individuals are found to be G6PD deficient and 22 samples are heterozygous that is, carriers. The percentage of G6PD-deficient $(\mathrm{Gd}+/+)$ and G6PD carrier $(\mathrm{Gd}+/ \mathrm{Gd}-)$ phenotypes were $10 \%$ and $11 \%$, respectively. The frequency of normal allele $(\mathrm{Gd}+)$ was 0.8283 , and frequency of mutant allele $(\mathrm{Gd}-$ ) was 0.172 (Table 1). In total 97 female samples, 9 are glucose-6-phosphate dehydrogenase deficient and 22 are carriers while in males 11 are glucose-6-phosphate dehydrogenase deficient. G6PD deficiency is an X-linked recessive trait, it is predominantly a disease of males. But in present study the percentage of G6PD deficiency in females and males is found to be $9.3 \%$ and $10.7 \%$, respectively. The percentage of female deficient is quite high. The reason may be the small sample size.

Several reports regarding G6PD deficiency were published in several caste groups/tribes like Parsee [13], Muslim [20], Brahmin [21-23], Jat [22], Rajputs [18], Vatalya Prajapati [24], Nagas [25], Kharia [26], Bhuyan [26], Danguria tharu [27], Kabui [20], and so forth. The frequency is higher among the tribals than the caste populations [15]. According to Bhasin and Walter [28], the frequency of G6PD deficiency among Indian population as a whole ranges from complete absence to $27 \%$. It is higher among the scheduled tribes as compared to other ethnic groups. G6PD-deficient allele frequency is comparatively higher in North and West Indian zones, whereas in South India it is uniformly low except in Andhra Pradesh and Tamil Nadu. Prevalence of G6PD deficiency is generally $0-10 \%$, although some communities may have higher prevalence: $27.5 \%$ for the Vataliya Prajapati community in Western India [24] and 27.1\% for the Angami Nagas, a tribal group in Northeastern India [25]. In present study, the G6PD deficiency in scheduled caste population is observed $10 \%$ which is comparable with the earlier reports in the same caste group. So it is evident from the observation of the present study that the G6PD deficiency is quite high in eastern Uttar Pradesh, and it is need of the hour to explore the different caste population of Eastern Uttar Pradesh population for G6PD deficiency, because UP population is genetically very less explored.

G6PD deficiency was mainly found in populations originating from tropical and subtropical areas of the world. The geographical distribution was similar to that of falciparum malaria, and suggested G6PD deficiency similar to the sickling trait owed its distribution to selection by this malaria organism [29]. The deficiency of G6PD is found in a belt extending from the Mediterranean area through Southwest Asia and India to Southeast Asia. Several epidemiological studies have identified pockets in Asia and the Middle East with prevalence of the disease as high as $62 \%$ in Kurdish Jews [30] and 31\% in Northern Vietnam [31]. Frequency of G6PD deficiency varies worldwide among different ethnic groups ranging from 20 to 30\% in Greece, 6\% in Saudi Arabia, and $5.5 \%$ in South China [32]. In Africa, the prevalence of G6PD deficiency has been reported as high as $28.1 \%$ in Southwest Nigeria [33], 22.5\% in Congo (Brazzaville) [34], 15.7\% in Mali (Bamako) [35], 13.0\% in Uganda [36], and 9.0-15.5\% in Gabon [37]. Numerous reports have been published on this genetic disorder in various Asian countries like Indonesia [38], Thailand [39], Malaysia [40], Taiwan [41], Bangladesh [42], Pakistan [43, 44], China [45], and Myanmar [46]. In Southeast Asia, the prevalence of G6PD deficiency differs greatly by region and ethic group and variants are similarly 
TABLE 2: Percentage of G6PD deficiency in different populations.

\begin{tabular}{lcc}
\hline Author & Country/population & $\begin{array}{c}\text { Percentage of } \\
\text { G6PD } \\
\text { deficiency }\end{array}$ \\
\hline Iwai et al. [47] & Myanmar & $10.8 \%$ \\
Hilmi et al. [50] & Iraq & $6.1 \%$ \\
Usanga and Ameen [51] & Iran & $11.6 \%$ \\
May et al. [33] & Nigeria & $15.7 \%$ \\
Al-Riyami and Ebrahim & Oman & $2-29 \%$ \\
[52] & Lebanon & $2.1 \%$ \\
Usanga and Ameen [51] & UAE & $11 \%$ \\
Bayoumi et al. [53] & Egypt & $5.9 \%$ \\
Hussein et al. [54] & Bahrain & $18 \%$ \\
Al-Arrayed [55] & Turkey & $0.5-20 \%$ \\
Atlay and Gumruk [56] & Syria & $30 \%$ \\
Usanga and Ameen [51] & Tanzania & $4.43-11.32 \%$ \\
Segeja et al. [57] & Yamen & $6.2 \%$ \\
White et al. [58] & Uganda & $13 \%$ \\
Davis et al. [36] & Saudi Arabia & $1-39.8 \%$ \\
Alabdulaali et al. [59] & Kuwait & $5.5 \%$ \\
Usanga and Ameen [51] & Jordan & $3.6 \%$ \\
Usanga and Ameen [51] & Bangladesh & $3.33-20 \%$ \\
Akhter et al. [42] & Thailand & $3-18 \%$ \\
Nuchprayoon et al. [39] & Vietnam & $2.3 \%$ \\
Matsuoka et al. [60] & Cambodia & $7 \%$ \\
Matsuoka et al. [61] & Pakistan & $1.07-3.17 \%$ \\
Ali et al. [43] & South China & $5.5 \%$ \\
Chan and Todd [62] & & \\
\hline & & \\
\hline
\end{tabular}

diverse. For example, in Myanmar, Iwai et al. [47] found prevalence of G6PD deficiency as high as $10.8 \%$ for the Shan people, $7.3 \%$ in the dominant ethnic group the Burma, and absent in the Akha, despite a regional proximity to the Shan. Table 2 shows percentages of G6PD deficiency reported from several Mediterranean, African, and Asian countries. As evident from the table, the highest frequency of G6PD deficiency is in Mediterranean countries like Syria (30\%) and Southwest Asia like Saudi Arabia (39.8\%), but frequency is low in Southeast Asian countries like China (5.5\%), Bangladesh (3.33-20\%), Myanmar (10.8\%), and Vietnam (2.3\%).

Investigations of enzyme in different human populations have shown more than 300 variants, and most of them are relatively rare, but some have appreciable frequencies in certain localized populations [48, 49]. So far several different G6PD variants are reported from India, namely, G6PD* Mediterranean, G6PD* Orissa, G6PD* Andhra Pradesh, G6PD*Cutch, G6PD* Jammu, G6PD* Kerala-Kalyan, G6PD* Porbandar, G6PD*Chatham, G6PD* Insuli, G6PD*Coimbra, and G6PD*West Bengal have been reported from India.

Early detection and prevention is the key strategy to successful management and control of G6PD deficiency. Genetic counseling, prenatal diagnosis, health education, and public awareness can provide benefits by way of preventive genetics to the affected individuals and their families. It is emphasized that there is further need to evaluate the clinical and prognostic aspects of the G6PD enzyme deficiency among the population of Eastern Uttar Pradesh, which will yield some definite insights into this genetic health problem in Uttar Pradesh.

\section{Acknowledgments}

The authors are grateful to the scheduled caste population of Uttar Pradesh, who participated in this study and without their cooperation this study could not be completed. The financial support from the University Grants Commission, New Delhi (Grant no. 39-968/2010(SR)) to P. Kumar is gratefully acknowledged.

\section{References}

[1] R. F. Kletzien, P. K. W. Harris, and L. A. Foellmi, "Glucose-6phosphate dehydrogenase: a 'housekeeping' enzyme subject to tissue-specific regulation by hormones, nutrients, and oxidant stress,” The FASEB Journal, vol. 8, no. 2, pp. 174-181, 1994.

[2] L. Luzzatto, A. Mehta, and T. Vulliamy, "Glucose 6-phosphate dehydrogenase deficiency," in The Metabolic and Molecular Bases of Inherited Disease, C. R. Scriver, A. L. Beaudet, W. S. Sly, and D. Valle, Eds., vol. 3, pp. 4517-4533, McGraw-Hill, New York, NY, USA, 8th edition, 2001.

[3] L. Luzzatto and G. Battistuzzi, "Glucose-6-phosphate dehydrogenase.," Advances in Human Genetics, vol. 14, pp. 217386, 1985.

[4] R. Notaro, A. Afolayan, and L. Luzzatto, "Human mutations in glucose 6-phosphate dehydrogenase reflect evolutionary history," The FASEB Journal, vol. 14, no. 3, pp. 485-494, 2000.

[5] T. Vulliamy, E. Beutler, and L. Luzzatto, "Variants of glucose6-phosphate dehydrogenase are due to missense mutations spread throughout the coding region of the gene," Human Mutation, vol. 2, no. 3, pp. 159-167, 1993.

[6] E. Beutler, "The hemolytic effect of primaquine and related compounds: a review," Blood, vol. 14, no. 2, pp. 103-139, 1959.

[7] Z. Spolarics, M. Siddiqi, J. H. Siegel et al., "Increased incidence of sepsis and altered monocyte functions in severely injured type A- glucose-6-phosphate dehydrogenase-deficient African American trauma patients," Critical Care Medicine, vol. 29, no. 4, pp. 728-736, 2001.

[8] E. Y. Chen, A. Cheng, A. Lee et al., "Sequence of human glucose-6-phosphate dehydrogenase cloned in plasmids and a yeast artificial chromosome," Genomics, vol. 10, no. 3, pp. 792800,1991

[9] P. Cohen and M. A. Rosemeyer, "Human glucose-6-phosphate dehydrogenase: purification of the erythrocyte enzyme and the influence of ions on its activity," European Journal of Biochemistry, vol. 8, no. 1, pp. 1-7, 1969.

[10] S. A. Tishkoff, R. Varkonyi, N. Cahinhinan et al., "Haplotype diversity and linkage disequilibrium at human G6PD: recent origin of alleles that confer malarial resistance," Science, vol. 293, no. 5529, pp. 455-462, 2001.

[11] E. F. Roth, C. Raventos-Suarez, A. Rinaldi, and R. L. Nagel, "Glucose-6-phosphate dehydrogenase deficiency inhibits in vitro growth of Plasmodium falciparum.," Proceedings of the National Academy of Sciences of the United States of America, vol. 80 , no. 1 , pp. 298-299, 1983. 
[12] E. A. Usanga and L. Luzzatto, "Adaptation of Plasmodium falciparum to glucose 6-phosphate dehydrogenase-deficient host red cells by production of parasite-encoded enzyme," Nature, vol. 313, no. 6005, pp. 793-795, 1985.

[13] A. J. Baxi, V. Balakrishnan, J. V. Undevia, and L. D. Sanghvi, "Glucose-6-phosphate dehydrogenase deficiency in the Parsee community, Bombay." Indian journal of medical sciences, vol. 17, pp. 493-500, 1963.

[14] S. N. Naik, "Glucose-6-phosphate dehydrogenase deficiency in India and its clinical significance.," The Journal of the Association of Physicians of India, vol. 42, no. 3, pp. 229-234, 1994.

[15] V. Tripathy and B. Reddy, "Present status of understanding on the G6PD deficiency and natural selection," Journal of Postgraduate Medicine, vol. 53, no. 3, pp. 193-202, 2007.

[16] R. Samatani, P. R. Mondal, and K. N. Saraswathy, "Glucose-6phosphate dehydrogenase deficiency and sickle cell hemoglobin among the Warli tribe of Dadra and Nagar Haveli," The Anthropologist, vol. 10, no. 4, pp. 301-303, 2008.

[17] M. Asghar and M. P. Sachdeva, "Glucose-6-phosphate dehydrogenase deficiency and sickle cell hemoglobin among the Dhodias of Dadra Nagar Haveli," The Anthropologist, vol. 11, no. 1, pp. 61-62, 2009.

[18] N. A. Devi and M. P. Sachdeva, "Sickle cell haemoglobin and glucose-6- phosphate dehydrogenase deficiency among the rajputs of dadra and nagar haveli," The Anthropologist, vol. 11, no. 1, pp. 45-47, 2009.

[19] G. J. Brewer, A. R. Tarlov, and A. S. Alving, "The methemoglobin reduction test for primaquine-type sensitivity of erythrocytes. A simplified procedure for detecting a specific hypersusceptibility to drug hemolysis.," The Journal of the American Medical Association, vol. 180, pp. 386-388, 1962.

[20] N. Achoubi, M. Asghar, S. Y. Meitei, M. P. Sachdeva, K. N. Sarawathy, and B. Murry, "Haemoglobinopathies and glucose6-phosphate dehydrogenase deficiency in a malaria endemic region of Manipur, northeast India," Anthropological Science, vol. 118, no. 3, pp. 201-204, 2011.

[21] P. K. Sidhu, K. Kaur, I. Kumar, and S. Lata, "Glucose-6phosphate dehydrogenase deficiency in blood donors: screening by micromethaemoglobin reduction test," Indian Journal of Pathology and Microbiology, vol. 44, no. 1, pp. 23-25, 2001.

[22] A. Santhi and M. P. Sachdeva, "Glucose-6-phosphate dehydrogenase deficiency among the jats and brahmins of sampla (Haryana)," The Anthropologist, vol. 6, no. 4, pp. 291-292, 2004.

[23] K. N. Saraswathy and S. Aggarwal, "Study of glucose-6- phosphate dehydrogenase deficiency and sickle cell anemia among the Tamil Brahmins of Delhi," The Anthropologist, vol. 7, no. 1, pp. 45-47, 2005.

[24] S. C. Gupte, A. N. Shaw, and K. C. Shah, "Hematological findings and severity of G6PD deficiency in Vataliya Prajapati subjects," Journal of Association of Physicians of India, vol. 53, pp. 1027-1030, 2005.

[25] P. K. Seth and S. Seth, "Biogenetical studies of Nagas: glucose6-phosphate dehydrogenase deficiency in Angami Nagas.," Human Biology, vol. 43, no. 4, pp. 557-561, 1971.

[26] R. S. Balgir, "Genetic burden of red cell enzyme glucose-6phosphate dehydrogenase deficiency in two major Scheduled Tribes of Sundargarh district, Northwestern Orissa, India," Current Science, vol. 92, no. 6, pp. 768-774, 2007.

[27] T. P. Sharma and Rajkumari, "Glucose-6-phosphate dehydrogenase deficiency in Danguria Tharu settled in Baharaich district of Uttar Pradesh," The Anthropologist, vol. 12, no. 1, pp. 59-61, 2010.
[28] M. K. Bhasin and H. Walter, Genetic of Caste and Tribes of India, Kamla-Raj Enterprises, Delhi, India, 2001.

[29] M. K. Bhasin, "Genetics of castes and tribes of India: glucose- 6-phosphate dehydrogenase deficiency and abnormal haemoglobins (HbS and $\mathrm{HbE}$ )," International Journal of $\mathrm{Hu}$ man Genetics, vol. 6, no. 1, pp. 49-72, 2006.

[30] D. P. Steensma, J. D. Hoyer, and V. F. Fairbanks, "Hereditary red blood cell disorders in Middle Eastern patients," Mayo Clinic Proceedings, vol. 76, no. 3, pp. 285-293, 2001.

[31] P. Verlé, D. H. Nhan, T. T. Tinh et al., "Glucose-6-phosphate dehydrogenase deficiency in northern Vietnam," Tropical Medicine and International Health, vol. 5, no. 3, pp. 203-206, 2000.

[32] A. S. Gandapur, F. Qureshi, G. Mustafa, S. Baksh, M. Ramzan, and M. A. Khan, "Frequency of glucose 6 phosphate dehydrogenase deficiency and related hemolytic anemia in Riyadh, Saudi Arabia.," Journal of Ayub Medical College, vol. 14, no. 3, pp. 24-26, 2002.

[33] J. May, C. G. Meyer, L. Großterlinden et al., "Red cell glucose6-phosphate dehydrogenase status and pyruvate kinase activity in a Nigerian population," Tropical Medicine and International Health, vol. 5, no. 2, pp. 119-123, 2000.

[34] J. C. Bouanga, R. Mouélé, C. Préhu, H. Wajcman, J. Feingold, and F. Galactéros, "Glucose-6-phosphate dehydrogenase deficiency and homozygous sickle cell disease in Congo," Human Heredity, vol. 48, no. 4, pp. 192-197, 1998.

[35] B. Duflo, A. Diallo, K. Toure, and G. Soula, "Glucose-6phosphate dehydrogenase deficiency in Mali. Epidemiology and pathological role," Bulletin de la Societe de Pathologie Exotique et de ses Filiales, vol. 72, no. 3, pp. 258-264, 1979.

[36] J. C. Davis, T. D. Clark, S. K. Kemble et al., "Longitudinal study of urban malaria in a cohort of Ugandan children: description of study site, census and recruitment," Malaria Journal, vol. 5, article no. 18, 2006.

[37] F. Migot-Nabias, L. E. Mombo, A. J. F. Luty et al., "Human genetic factors related to susceptibility to mild malaria in Gabon," Genes and Immunity, vol. 1, no. 7, pp. 435-441, 2000.

[38] H. Matsuoka, M. Arai, S. Yoshida et al., "Five different glucose6-phophate dehydrogenase (G6PD) variants found among 11 G6PD-deficient persons in Flores Island, Indonesia," Journal of Human Genetics, vol. 48, no. 10, pp. 541-544, 2003.

[39] I. Nuchprayoon, S. Sanpavat, and S. Nuchprayoon, "Glucose6-phosphate dehydrogenase (G6PD) mutations in Thailand: G6PD Viangchan $(871 \mathrm{G}>\mathrm{A})$ is the most common deficiency variant in the Thai population.," Human mutation, vol. 19, no. 2, p. 185, 2002.

[40] J. Wang, E. Luo, M. Hirai et al., "Nine different glucose6-phosphate dehydrogenase (G6PD) variants in a Malaysian population with Malay, Chinese, Indian and Orang Asli (Aboriginal Malaysian) backgrounds," Acta Medica Okayama, vol. 62, no. 5, pp. 327-332, 2008.

[41] H. Y. Ho, M. L. Cheng, S. F. Weng et al., "Glucose-6-phosphate dehydrogenase deficiency enhances enterovirus 71 infection," Journal of General Virology, vol. 89, no. 9, pp. 2080-2089, 2008.

[42] N. Akhter, N. Begum, and W. A. Khan, "Glucose-6-phosphate dehydrogenase (G6PD) status in neonatal jaundice and its relationship with severity of hyperbilirubinemia," Journal of Bangladesh Society of Physiologist, vol. 4, no. 2, pp. 71-76, 2009.

[43] N. Ali, M. Anwar, M. Ayyub, F. A. Bhatti, M. Nadeem, and A. Nadeem, "Frequency of glucose-6-phosphate dehydrogenase deficiency in some ethnic groups of Pakistan," Journal of the College of Physicians and Surgeons Pakistan, vol. 15, no. 3, pp. 137-141, 2005. 
[44] B. Moiz, A. Nasir, T. Moatter, Z. Ali Naqvi, and M. Khurshid, "Population study of $1311 \mathrm{C} / \mathrm{T}$ polymorphism of Glucose 6 Phosphate Dehydrogenase gene in Pakistan-an analysis of 715 X-chromosomes," BMC Genetics, vol. 10, article no. 41, 2009.

[45] C. S. Huang, K. L. Hung, M. J. Huang, Y. C. Li, T. H. Liu, and T. K. Tang, "Neonatal jaundice and molecular mutations in glucose-6-phosphate dehydrogenase deficient newborn infants," American Journal of Hematology, vol. 51, no. 1, pp. 1925, 1996.

[46] I. Nuchprayoon, C. Louicharoen, and W. Charoenvej, "Glucose-6-phosphate dehydrogenase mutations in Mon and Burmese of southern Myanmar," Journal of Human Genetics, vol. 53, no. 1, pp. 48-54, 2008.

[47] K. Iwai, A. Hirono, H. Matsuoka et al., "Distribution of glucose-6-phosphate dehydrogenase mutations in Southeast Asia," Human Genetics, vol. 108, no. 6, pp. 445-449, 2001.

[48] L. Luzzatto and A. Mehta, "Glucose-6-phos-phate dehydrogenase deficiency," in The Metabolic of Inherited Disease, C. R. Scriver, A. L. Baudet, W. S. Sly, and D Valle, Eds., pp. 2237 2265, McGraw-Hill, New York, NY, USA, 6th edition, 1989.

[49] E. Beutler, "The genetics of glucose-6-phosphate dehydrogenase deficiency," Seminars in Hematology, vol. 27, no. 2, pp. 137-164, 1990.

[50] F. A. Hilmi, N. A. Al-Allwi, M. Rassam, G. Al-Shamma, and A. Al-Hashimi, "Red cell glucose-6-phosphate dehydrogenase phenotypes in Iraq," Eastern Mediterranean Health Journal, vol. 8, no. 1, pp. 42-48, 2002.

[51] E. A. Usanga and R. Ameen, "Glucose-6-phosphate dehydrogenase deficiency in Kuwait, Syria, Egypt, Iran, Jordan and Lebanon," Human Heredity, vol. 50, no. 3, pp. 158-161, 2000.

[52] A. Al-Riyami and G. J. Ebrahim, "Genetic blood disorders survey in the Sultanate of Oman," Journal of Tropical Pediatrics, vol. 49, supplement 1, pp. i1-i20, 2003.

[53] R. A. Bayoumi, M. S. A. Nur-E-Kamal, M. Tadayyon et al., "Molecular characterization of erythrocyte glucose-6-phosphate dehydrogenase deficiency in Al-Ain District, United Arab Emirates," Human Heredity, vol. 46, no. 3, pp. 136-141, 1996.

[54] L. Hussein, G. Yamamah, and A. Saleh, "Glucose-6-phosphate dehydrogenase deficiency and sulfadimidin acetylation phenotypes in Egyptian oases," Biochemical Genetics, vol. 30, no. 3-4, pp. 113-121, 1992.

[55] S. Al Arrayed, "Campaign to control genetic blood diseases in Bahrain," Community Genetics, vol. 8, no. 1, pp. 52-55, 2005.

[56] C. Altay and F. Gumruk, "Red cell glucose-6-phosphate dehydrogenase deficiency in Turkey," Turkish Journal of Hematology, vol. 25, no. 1, pp. 1-7, 2008.

[57] M. D. Segeja, B. P. Mmbando, M. L. Kamugisha et al., "Prevalence of glucose-6-phosphate dehydrogenase deficiency and haemoglobin $\mathrm{S}$ in high and moderate malaria transmission areas of Muheza, north-eastern Tanzania.," Tanzania Journal of Health Research, vol. 10, no. 1, pp. 9-13, 2008.

[58] J. M. White, M. Byrne, R. Richards, T. Buchanan, E. Katsoulis, and K. Weerasingh, "Red cell genetic abnormalities in Peninsular Arabs: sickle haemoglobin, G6PD deficiency, and alpha and beta thalassaemia," Journal of Medical Geneics, vol. 23, no. 3, pp. 245-251, 1986.

[59] M. K. Alabdulaali, K. M. Alayed, A. F. Alshaikh, and S. A. Almashhadani, "Prevalence of glucose-6-phosphate dehydrogenase deficiency and sickle cell trait among blood donors in Riyadh," Asian Journal of Transfusion Science, vol. 4, no. 1, pp. 31-33, 2010.
[60] H. Matsuoka, D. T. V. Thuan, H. Van Thien et al., "Seven different glucose-6-phosphate dehydrogenase variants including a new variant distributed in Lam Dong Province in southern Vietnam," Acta Medica Okayama, vol. 61, no. 4, pp. 213-219, 2007.

[61] H. Matsuoka, C. Nguon, T. Kanbe et al., "Glucose-6-phosphate dehydrogenase (G6PD) mutations in Cambodia: G6PD Viangchan $(871 \mathrm{G}>\mathrm{A})$ is the most common variant in the Cambodian population," Journal of Human Genetics, vol. 50, no. 9, pp. 468-472, 2005.

[62] T. K. Chan and D. Todd, "Characteristics and distribution of glucose-6-phosphate dehydrogenase-deficient variants in South China.," American Journal of Human Genetics, vol. 24, no. 4, pp. 475-484, 1972. 


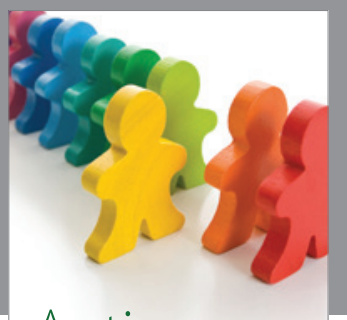

Autism

Research and Treatment
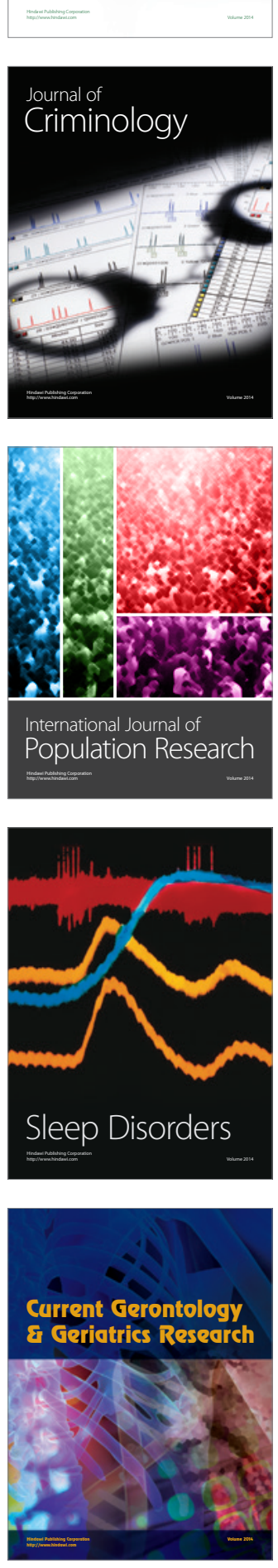
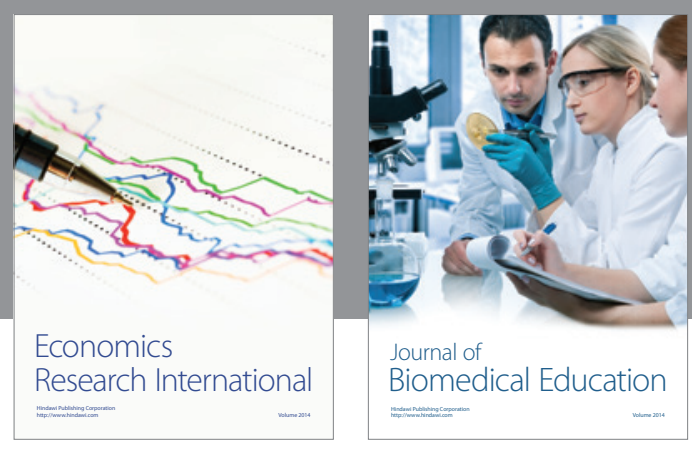

Journal of

Biomedical Education

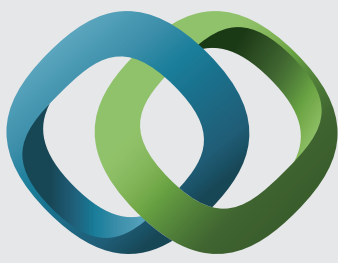

\section{Hindawi}

Submit your manuscripts at

http://www.hindawi.com
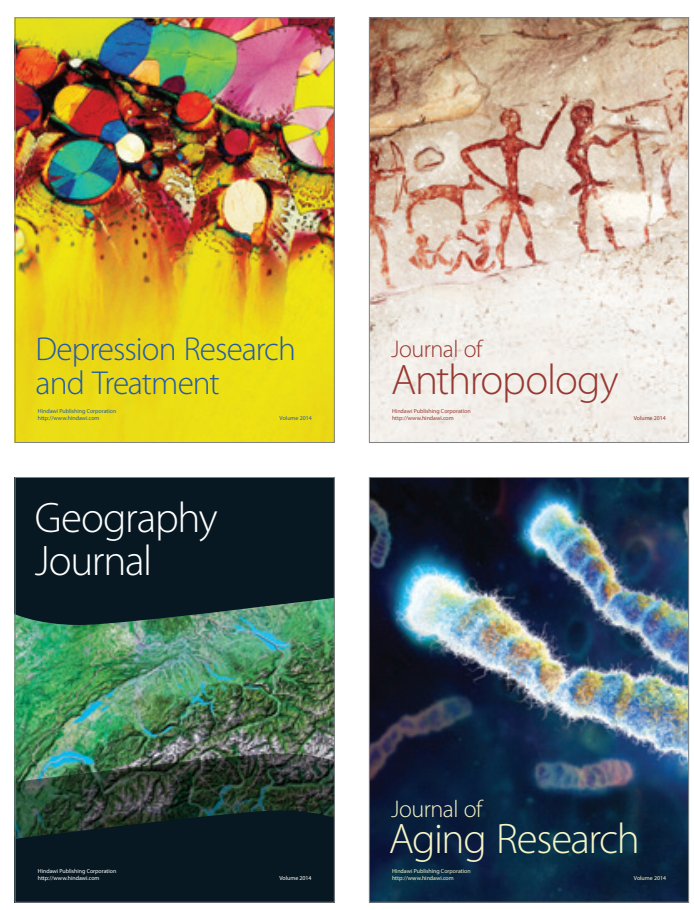

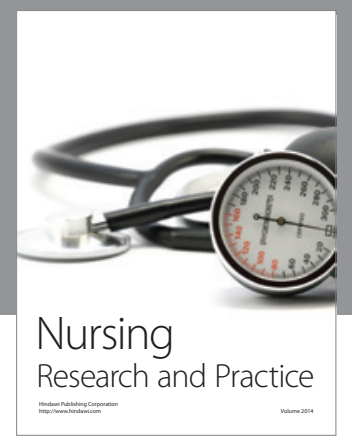

Nursing

Research and Practice

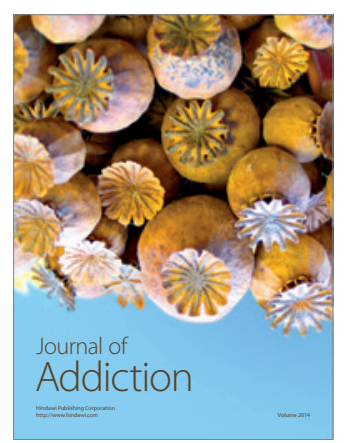

Child Development

Research

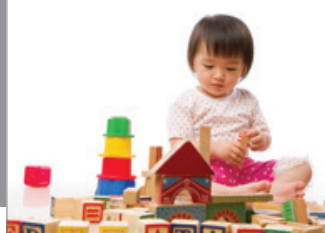

迥
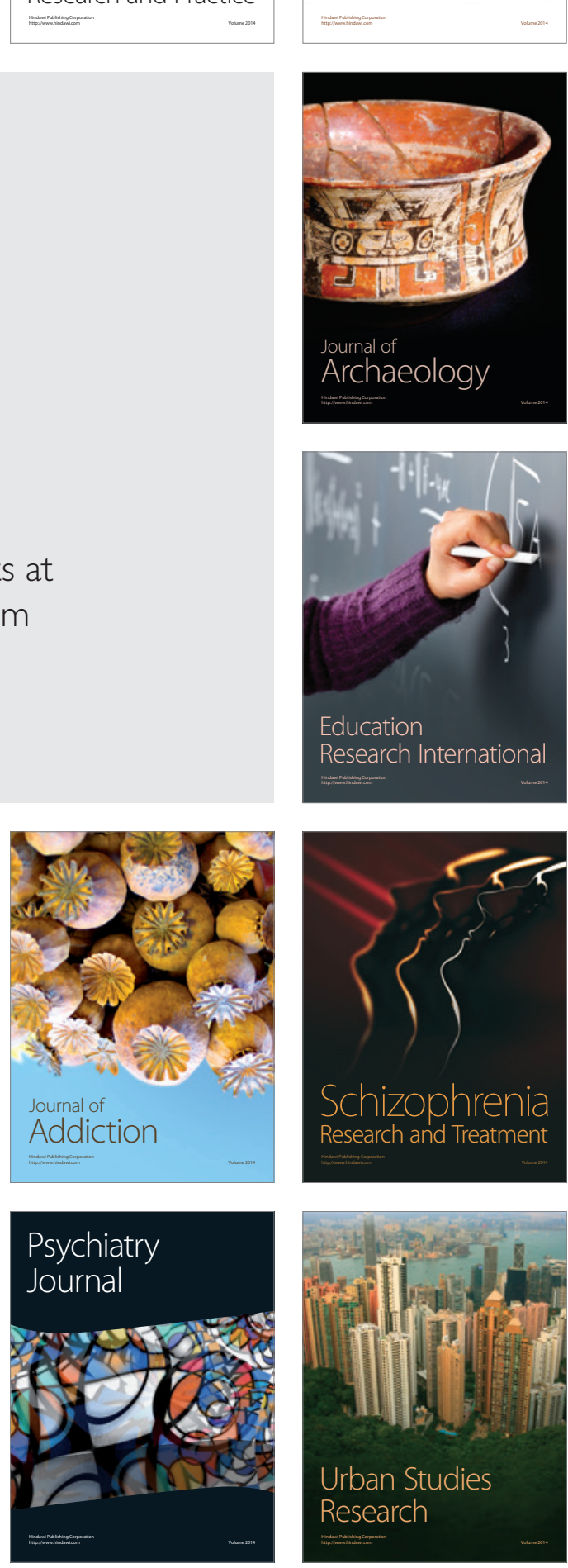